\title{
Chapter 12 \\ The Effects of Radioactive Contamination on the Forestry Industry and Commercial Mushroom-Log Production in Fukushima, Japan
}

\section{Satoru Miura}

\begin{abstract}
The accident at the Fukushima Daiichi nuclear power plant in 2011 left surrounding residential, agricultural, and forested areas contaminated with radiation on a massive scale. To encourage evacuees to return to their homes and resume agricultural practices, large-scale decontamination of radioactive zones is ongoing in residential and agricultural areas. However, contamination of forests is extensive and decontamination efforts have been limited by remote access, significant labor requirements, and the considerable amount of anticipated radioactive waste. Consequently, there has been no large-scale effort to decontaminate forests as there has been for residential and agricultural land. In this paper, we examine the current protection of forests from radioactive contamination and discuss measures required to promote forest restoration. In addition, we consider how forest contamination relates to radiation exposure in humans and summarize the state of the forestry industry since the Fukushima accident. We also consider how radiation affects forest products in Fukushima, emphasizing mushroom-log production. Finally, we examine the challenges surrounding the reconstruction and revival of forests and forestry in Fukushima.
\end{abstract}

Keywords Forest restoration - Hardwood forest management - Mushroom cultivation $\bullet$ Mushroom $\log _{\mathrm{s}} \cdot$ Radiocesium transfer

\footnotetext{
S. Miura $(\bowtie)$

Department of Forest Site Environment, Forestry and Forest Products Research Institute, Matsunosato 1, Tsukuba, Ibaraki 305-8687, Japan e-mail: miura@ffpri.affrc.go.jp 


\subsection{Current Forest Contamination and Remediation Efforts}

\subsubsection{External Exposure}

The effect of forests contaminated with radiation on humans depends on whether the radiation exposure is external or internal. External exposure can occur through either close contact with contaminated timber or exposure to contaminated forest sites during outdoor activities. The highest level of radioactive contamination found in timber from Fukushima Prefecture was $414 \mathrm{~Bq} / \mathrm{kg}$ (479 Bq/kg dry weight) and in 2012, the Forestry Agency, Japan estimated that a person living in a room made from this contaminated timber would incur an additional $0.012 \mathrm{mSv}$ per year (Forestry Agency 2012a). This is $1.2 \%$ of the accepted additional dose of $1 \mathrm{mSv}$ per year and would have a negligible effect on human health. However, in Japan, there is no regulation of the radiation levels of building materials taken from conifer forests, and therefore the Fukushima Lumber Co-operative Union has adopted a limit of 1000 gamma ray counts per minute, using a Geiger-Müller counter, as this is the permissible level for contaminated materials from a laboratory with radioisotope analysis (Fukushima Lumber Cooperative Unions 2012). This selfregulation and monitoring of timber radiation levels is to counter and refute unfounded concerns regarding the use of timber from Fukushima Prefecture and to promote its distribution.

Radiation exposure sustained during outdoor activities in contaminated forests depends on the air dose rate and time spent in contaminated areas. This is of concern to forestry workers and decontamination crews, due to the significant amounts of time they might spend in contaminated forests. Furthermore, contaminated forests will also affect people visiting for recreational activities, although they generally spend less time in contaminated areas than forestry workers. To ensure safer conditions, the government has enforced the Ordinance on Prevention of Ionizing Radiation Hazards, which aims to protect workers by managing exposure doses based on the air dose rate and exposure to radioactive materials in the workplace (Ministry of Health, Labour and Welfare, Japan 2013a). For workers other than those involved in decontamination, this law will keep occupational exposure dosage below the limit set by the International Commission on Radiological Protection (Valentin 2007). In addition, the Forestry Agency and the Fukushima Prefectural government are implementing policies to reduce exposure rates to forestry workers, such as equipping large forestry machinery with lead shielding and using substances to reduce the air dose rate in contaminated areas (Forestry Agency 2014a). Moreover, the Nuclear Regulation Authority is providing safety information and countermeasures to reduce radiation exposure to people returning home (Nuclear Regulation Authority 2013). Finally, government policy has shifted its emphasis from estimates based on air dose rates to values obtained from dosimeters that track individuals. 


\subsubsection{Internal Exposure}

Consumption of contaminated food is the primary means of internal radiation exposure to humans. Forests in Japan produce many food products, including sansai (edible wild plants), bamboo shoots, fruits, nuts, and wild game, but mushrooms are by far the most economically important forest food product (Forestry Agency 2014f). Additionally, artificially cultivated mushrooms are the only forest food product that is consumed on a large, commercial scale.

Immediately after the Fukushima accident in March 2011, the Japanese government set a maximum tolerable level of radioactivity in food at $500 \mathrm{~Bq} / \mathrm{kg}$ for adults to protect against internal radiation exposure (Ministry of Health, Labor and Welfare, Japan 2011). Prefectural governments inspected the radioactivity of foods and reported findings to the Ministry of Health, Labor and Welfare, and the government prevented distribution and shipping of food that exceeded the radiation limits. This monitoring system applied to conventional agriculture as well as food grown in forests. The Fukushima government abided by and implemented such a monitoring system to inspect agricultural products and protect the public from consuming excessively contaminated food. For example, rice, which is the main agricultural product in Fukushima, was inspected bag-by-bag in 2012 to allay consumer fears of contamination (Nihei et al. 2015). The government initiated similar inspections at the shipment stage to ensure the safety of forest food products, including mushrooms. However, in April 2012, the Japanese government revised the radioactive cesium limit for general food to $100 \mathrm{~Bq} / \mathrm{kg}$ (Ministry of Health, Labour and Welfare, Japan 2012).

The Ministry of Health, Labor and Welfare, Japan set these regulations for food in the general market, but no such guidelines were set for food produced, hunted or gathered by individuals for their own use. This is of particular concern, as people often collect mushrooms and sansai in the mountainous areas of Fukushima. Shortly after the Fukushima nuclear accident, the government published information about radioactive contamination, including a radiation map and shipping restrictions on agricultural and forest products. This was the extent of protection against radiation health effects for people collecting their own food. However, local authorities have provided community centers with the equipment needed to test radiation levels in food to provide comprehensive information regarding the impact of radiation.

The Japanese government monitored radioactive Cs (Cs-134, Cs-137) levels in food through market-basket samples in autumn 2012 at 15 locations nationwide, including Fukushima. All calculated annual doses were less than $1 \%$ of $1 \mathrm{mSv}$, far below the permissible annual dose (Ministry of Health, Labor and Welfare, Japan 2013b). However, radioactive contamination of forests has affected people economically and altered rural lifestyles, as forests comprise $71 \%$ of Fukushima Prefecture and many people make a living from harvesting forest products. Large-scale radioactive contamination of forests is the main problem interfering with revitalization and reconstruction following the Fukushima nuclear accident. 


\subsubsection{Ecological Damage and Extent of Radioactive Contamination}

In addition to human exposure to radiation through contaminated forests and forest products, radiation has caused ecological loss and damage. Although reports of mutations and ecological devastation are limited, radiation has affected lycaenid butterflies (Hiyama et al. 2012), birds and animals (Ishida 2013), and earthworms (Hasegawa et al. 2013). Moreover, organisms have absorbed radioactive particles from the environment (Murakami et al. 2014). This differs from the Chernobyl nuclear disaster, after which radiation emissions devastated trees and forests over a large area (Arkhipov et al. 1994).

In addition to damage to forests themselves, there is concern that radioactive materials can move from forests into rivers, agricultural land, coastal waters or residential areas. Fallen leaves blowing from contaminated forests to decontaminated residential areas, and irrigation water from streams originating in contaminated forests, could spread radioactivity. The government and universities monitor contamination of forest streams and have found that such contamination is restricted to periods of heavy rain (Forestry and Forest Products Research Institute 2012). When there is no rainfall, streams are not turbid and radioactive Cs are nearly undetectable. However, during heavy rainfall, tumultuous water stirs up radioactive sediment. Still, when suspended matter is filtered out, very little radioactive Cs remain. This indicates that ionic radioactive Cs levels are negligible and that clay particles absorb the majority of the radiation. Furthermore, the amount of radioactive materials flowing in forest streams was found to be less than $1 \%$ of the total deposited material (Hayashi 2013; Takahashi 2013). Conversely, after removing contaminated leaves and other detritus from the forest floor, thereby leaving the ground exposed, considerable amounts of radioactive soil and particulate matter were discharged from the bare ground (Forestry Agency 2014a). This suggests that minimizing soil movement by leaving the forest floor undisturbed and covered with leaves and other organic material will mitigate transfer of radioactive matter from forests to neighboring areas.

Studies indicate that forests act as reservoirs for radioactive material. Fixed-site monitoring in forest ecosystems showed that deposition of radioactive Cs did not change considerably from 2011 to 2013 (Forestry Agency 2014b). Following the Fukushima nuclear accident, there were concerns that radioactive material might spread through soil erosion in steep environments with high rainfall, characteristic of forests in Fukushima. However, even under such environmental conditions, through management of forests and maintenance of forest floor cover, forests will retain the majority of the fallen radioactive material.

Compared to regions contaminated by the Chernobyl nuclear accident, areas around Fukushima are densely populated and forestry activities are more common. However, using forests as a sink for radioactive substances could be a viable option. Decontamination requires collecting contaminants and although it is possible to manage radioactive substances, it is not possible to eliminate radioactivity. 
Decontamination strategies should prioritize low-cost management to ensure that radioactive substances do not spread until their radioactivity reaches a safe level.

\subsubsection{Summary of Radiation Mitigation in Forests}

Most radioactive materials in a forest remain within the forest ecosystem. While there has been no active decontamination program for forests as there has been in agricultural and residential areas, we have pursued means to protect human health. For example, we understand the distribution of radioactive substances in forests and have investigated measures to keep radiation at safe levels for people. Moreover, we have examined how to prevent radioactive contaminants in streams from flowing out of forests. Still, we have not addressed all issues concerning human and environmental health, such as radiation in logs for mushroom cultivation.

Within the context of tree physiology, the problem of radiation in logs begins with the movement of radioactive Cs into trees. After the Chernobyl nuclear disaster, the International Atomic Energy Agency (2002) developed models to predict the movement of radioactive substances into trees and these have since been applied in Japan (Hashimoto et al. 2013). However, data were collected only shortly after the Fukushima accident and additional data are required to improve predictions. Predictions should also be species-specific, especially for species used for cultivation of mushrooms, such as konara oak (Quercus serrata). The remainder of this report describes the movement of radioactive cesium into broad-leaf trees used for mushroom cultivation.

\subsection{Radioactive Contamination and Mushroom Cultivation}

\subsubsection{Mushroom Cultivation in Japan}

In Japan, mushrooms are a commercially important commodity that are usually artificially cultivated. There are two common methods of cultivating mushrooms: log cultivation (Fig. 12.1a) and sawdust substrate cultivation (Fig. 12.1b). For log cultivation, the fungal inoculum is implanted in small holes drilled in broadleaf logs kept either outside on bare ground, or inside a specialized facility. Sawdust substrate cultivation uses a mix of broadleaf sawdust and rice bran as the growth medium and the mushrooms develop inside specialized facilities. The flavor of log-cultivated shiitake mushrooms (Lentinus edodes) is generally preferred to those cultivated using the sawdust method. However, the industry uses the sawdust method more commonly; it accounts for $85 \%$ of shiitake production (Forestry Agency 2014c). 
Fig. 12.1 Shiitake mushroom (Lentinus edodes) cultures. (a) Mushroom-log cultivation; (b) Sawdust substrate cultivation (Photos by Hitoshi Neda)
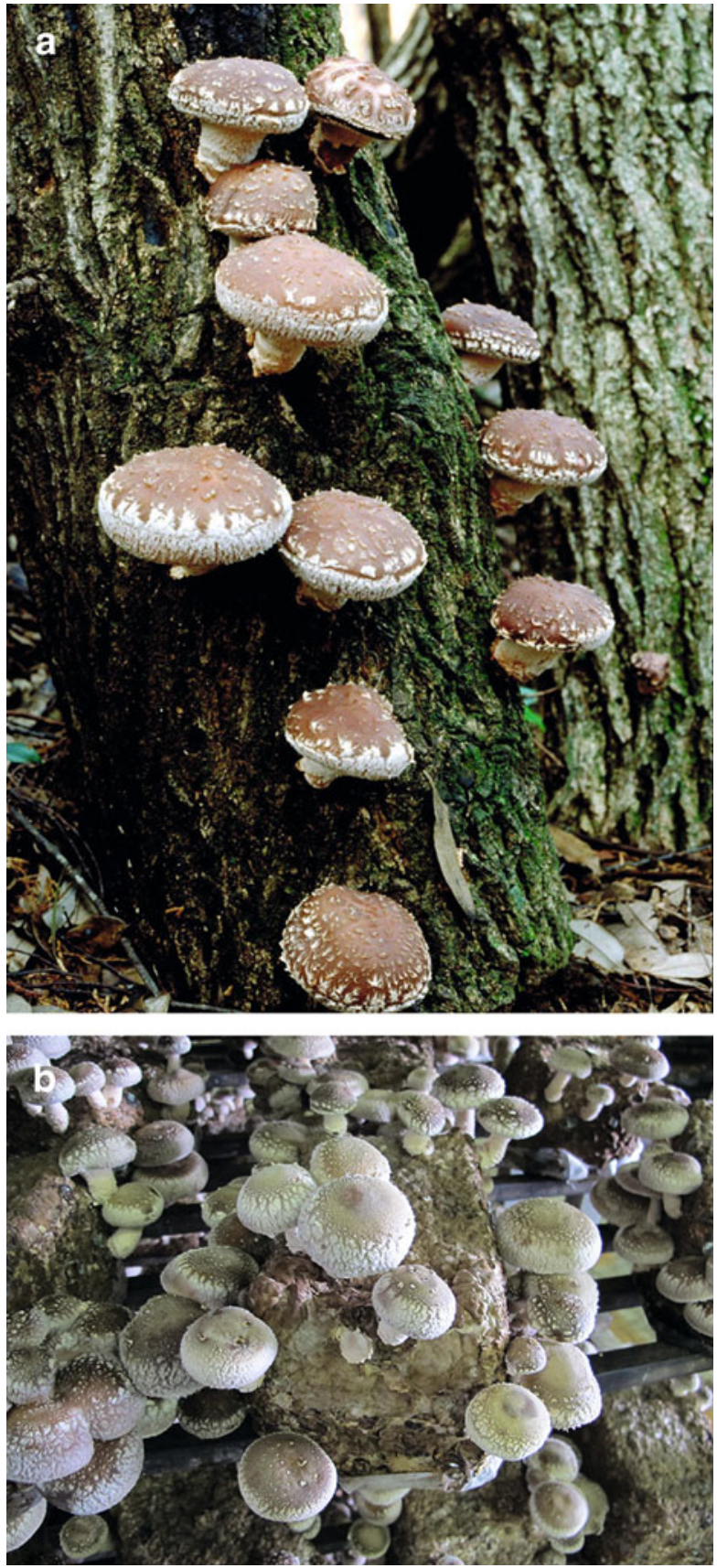


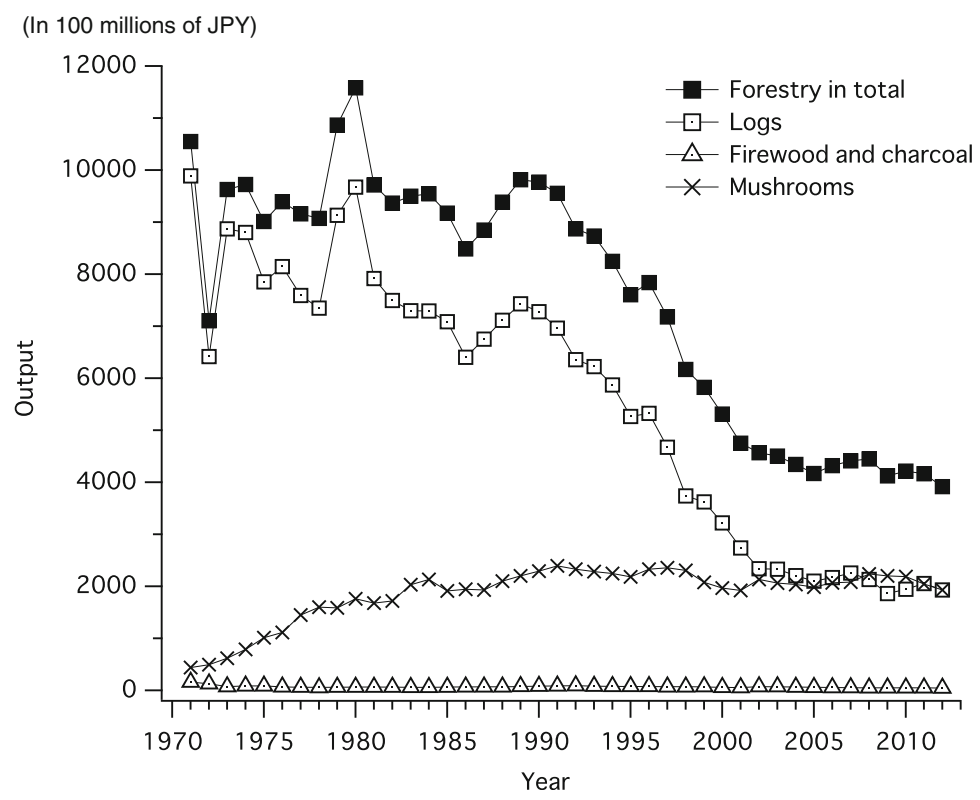

Fig. 12.2 Economic forestry output in Japan from 1971 to 2012

Mushroom cultivation increased gradually through the 1970s and 1980s, while timber production dramatically declined during the 1990s, resulting in the two industries having similar market values by the early 2000s (Fig. 12.2). In 2010, mushroom cultivation was worth 218.9 billion yen, representing $52 \%$ of the value of all forestry products (Table 12.1). However, agriculture and forestry production in Fukushima both dropped sharply after the nuclear accident, and while agricultural revenue was recovering by 2012, forestry revenue, including mushroom cultivation, took one more year to start to recover.

Mushroom cultivation depends on wood as the culture medium. Before the nuclear accident, Fukushima Prefecture was the largest producer of wood for this purpose. In 2009, $10 \%$ of wood for mushroom cultivation was imported from outside the prefecture in which the mushrooms were produced, and Fukushima supplied most of this wood to 22 of 47 prefectures (Forestry Agency 2014d). Hardwood production numbers reflect this, and in 2010 Fukushima Prefecture ranked number three among prefectures in hardwood production by volume in Japan (Table 12.2). After the nuclear accident in 2011, wood supply for mushroom cultivation from Fukushima almost completely ceased, thus affecting mushroom cultivation nationwide. The Forestry Agency and stakeholders in the mushroom industry demanded an adjustment scheme in autumn 2011 (Forestry Agency 2011). However, as of 2014, the mismatch between supply and demand had not been rectified. 
Table 12.1 Total agricultural and forestry output and the breakdown of forestry production in Japan and Fukushima before and after the Fukushima nuclear power plant accident

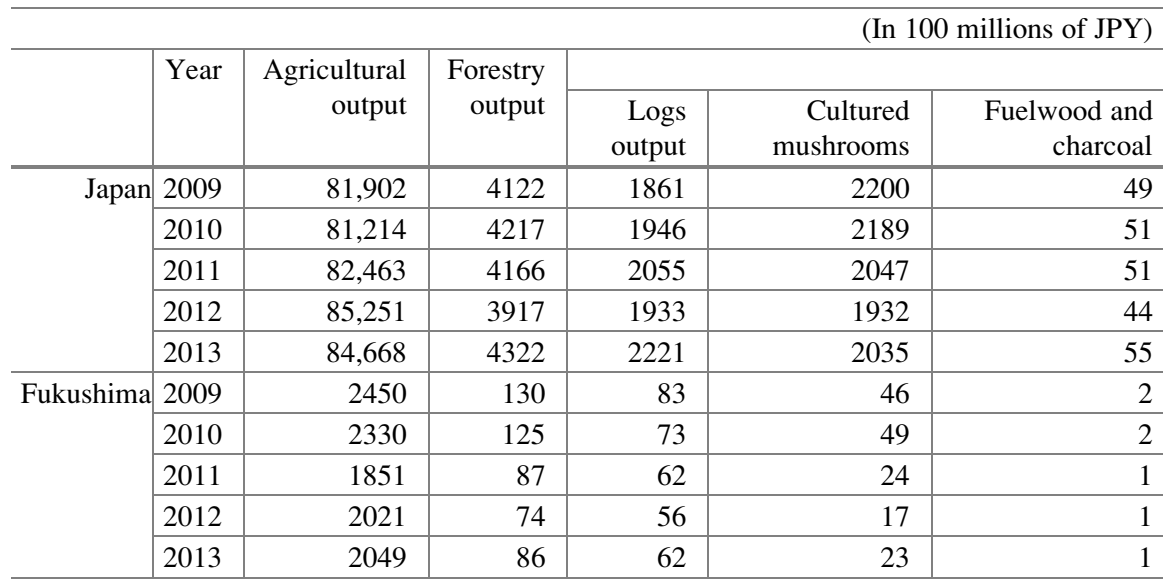

Data obtained from the Forestry Agency (Source: Statistics Department, Minister's Secretariat, Ministry of Agriculture, Forestry and Fisheries)

Table 12.2 Prefectures with the highest hardwood forest production in Japan in 2010 and 2012

\begin{tabular}{l|l|l|l|c}
\hline \multicolumn{3}{l}{} & \multicolumn{2}{l}{ (In 10 millions of JPY) } \\
\hline Year & 2010 & Hardwood production & Prefecture & Hardwood production \\
\hline Rank & Prefecture & 753 & Hokkaido & 649 \\
\hline 1 & Hokkaido & 358 & Iwate & 346 \\
\hline 2 & Iwate & 152 & Kagoshima & 144 \\
\hline 3 & Fukushima & 141 & Hiroshima & 116 \\
\hline 4 & Kagoshima & 95 & Shimane & 81 \\
\hline 5 & Miyazaki & 96 & Fukushima & 78 \\
\hline 6 & Hiroshima & 86 & Miyazaki & 59 \\
\hline 7 & Aomori & 63 & Aomori & 52 \\
\hline 8 & Shimane & 59 & Akita & 49 \\
\hline 9 & Miyagi & 53 & Yamagata & 48 \\
\hline 10 & Akita & 53 & Japan & 2062 \\
\hline
\end{tabular}

Data obtained from the Forestry Agency (Source: Statistics Department, Minister's Secretariat, Ministry of Agriculture, Forestry and Fisheries)

\subsubsection{Contamination of Mushroom Growth Media}

Mushrooms readily absorb and accumulate Cs (Kalač 2001). After the Chernobyl nuclear accident, mushrooms were among the most contaminated forest products, along with berries and game meat (International Atomic Energy Agency 2006). Following the Fukushima nuclear accident, food inspections across Japan revealed 
that wild-picked mushrooms had particularly high radioactive contamination; these inspections detected levels above allowable limits in prefectures as distant as Aomori and Nagano. As of autumn 2014, restrictions on mushroom shipments from ten prefectures remained in effect (Forestry Agency 2014e) and contamination of mushrooms was ubiquitous in eastern Japan. However, radioactive emissions from the Fukushima accident had a ${ }^{134} \mathrm{Cs}:{ }^{137} \mathrm{Cs}$ ratio of approximately $1: 1$, which had become 1:3 by autumn 2014 due to their different decay rates. However, most of the radioactive Cs in prefectures far from Fukushima is ${ }^{137} \mathrm{Cs}$; often no ${ }^{134} \mathrm{Cs}$ is present (Yamada 2013). In such samples, the ${ }^{137} \mathrm{Cs}$ contamination of mushrooms likely originates from atmospheric nuclear testing in the 1950s and 1960s. The Nuclear Regulation Authority has monitored this radioactive fallout since the late 1950s (Nuclear Regulation Authority 2014). Moreover, radioactive ${ }^{137} \mathrm{Cs}$ also reached Japan from the Chernobyl nuclear accident, but declined immediately to a steady level from an initial spike.

In 2011, the Japanese government set acceptable radiation levels for food, including mushrooms, at $500 \mathrm{~Bq} / \mathrm{kg}$, which was reduced to $100 \mathrm{~Bq} / \mathrm{kg}$ in 2012 . In response to this, the Forestry Agency immediately started to investigate maximum radioactivity levels for mushroom media to produce mushrooms below the allowable radiation limit. This investigation determined that the maximum contamination value for both $\log$ and sawdust media was $150 \mathrm{~Bq} / \mathrm{kg}$. However, a follow-up study adjusted these limits to $50 \mathrm{~Bq} / \mathrm{kg}$ for $\operatorname{logs}$ and $200 \mathrm{~Bq} / \mathrm{kg}$ for sawdust (Forestry Agency 2012b). The lower radioactivity limit for logs is due to greater variation in this medium, although purveyors of these logs consider the limit excessive.

In 2014, a study in Nakadori, Fukushima, found ${ }^{137}$ Cs levels from 500 to $800 \mathrm{~Bq} /$ $\mathrm{kg}$ in konara oak logs used for mushroom cultivation (Table 12.3); even the lowest contamination levels were tenfold the allowable limit. Moreover, the study site had a radiation contamination level of $100-300 \mathrm{kBq} / \mathrm{m}^{2}$ and the surveyed logs tested would have been live trees at the time of the Fukushima nuclear accident. Regardless, it seems that no konara oak logs from Nakadori or Hamadori regions are currently suitable for mushroom cultivation. Conversely, parts of the Aizu region in western Fukushima have lower contamination levels, and subsequently minimal production of logs for mushroom cultivation has been resumed.

The Forestry Agency published guidelines to manage log cultivation and maintain radioactivity within the set limits (Forestry Agency 2013). These include washing the mushroom logs and measures to prevent them from contacting contaminated soils. Another experiment, immersing logs in Prussian blue solution, which adsorbs radioactive cesium and prevents it from entering mushrooms, was extremely effective (Neda 2013). However, this adds to production costs and may color mushrooms blue, thereby reducing their value, rendering the technique unviable. While producing safe mushrooms is the priority, this has negatively affected the outlook for producers of mushroom logs in Fukushima Prefecture. 
Table 12.3 Radiocesium concentrations in stem wood and bark, and their weighted averages in logs used for mushroom cultivation ${ }^{\mathrm{a}}$

\begin{tabular}{l|l|l|l|l}
\hline Part of stem & Size & DBH $(\mathrm{cm})$ & ${ }^{134} \mathrm{Cs}^{\mathrm{b}}\left(\mathrm{Bq} \mathrm{kg}^{-1}\right)$ & ${ }^{137} \mathrm{Cs}^{\mathrm{b}}\left(\mathrm{Bq} \mathrm{kg}^{-1}\right)$ \\
\hline \multirow{3}{*}{ Stem wood } & Large & $\begin{array}{l}12.1,13.2, \\
13.6\end{array}$ & $95 \pm 5$ & $271 \pm 15$ \\
\cline { 2 - 5 } & Medium & $9.9,10.9$ & $93 \pm 15$ & $264 \pm 38$ \\
\cline { 2 - 5 } & Small & $\begin{array}{l}7.8,9.2, \\
10.0\end{array}$ & $55 \pm 4$ & $159 \pm 14$ \\
\hline \multirow{2}{*}{ Bark } & Large & & $727 \pm 21$ & $2083 \pm 71$ \\
\cline { 2 - 5 } & Medium & & $940 \pm 85$ & $2657 \pm 223$ \\
\cline { 2 - 5 } & Small & & $1047 \pm 190$ & $2998 \pm 547$ \\
\hline \multirow{2}{*}{$\begin{array}{l}\text { Weighted average of stem } \\
\text { wood and bark }\end{array}$} & Large & & $184 \pm 7$ & $524 \pm 19$ \\
\cline { 2 - 5 } & Medium & & $279 \pm 15$ & $789 \pm 42$ \\
\cline { 2 - 5 } & Small & & $250 \pm 69$ & $716 \pm 199$ \\
\hline
\end{tabular}

${ }^{a}$ Miura et al., unpublished data. Field survey was conducted in the Miyakoji area, Tamura, Fukushima in March 2014 (deposited amount of ${ }^{134} \mathrm{Cs}$ and ${ }^{137} \mathrm{Cs}$ by airborne monitoring on July 22011 was $100-300 \mathrm{kBq} \mathrm{m}^{-2}$. Air dose rate was $0.33 \mu \mathrm{Sv} \mathrm{h}^{-1}$ on March 18 2014)

${ }^{b}$ Average of two or three stems of each individual sample, calculated as the average of three discs at heights of $0.5,2$, and $4 \mathrm{~m}$. Radioactivity of stem wood and bark was determined by a germanium detector with counting error of 3 sigma

\subsection{Restoring Hardwood Production}

\subsubsection{Mushroom Log Production by Forest Cooperatives}

Fukushima Chuo Forest Cooperative is overseeing a major mushroom log production operation (Fig. 12.3) in the Abukuma Mountains west of the Fukushima Daiichi nuclear power plant. In 2010, the cooperative had a membership of 8590 and 51,531 ha of private forest. Before the Fukushima nuclear accident, the cooperative successfully focused on producing high-quality hardwood logs for mushroom cultivation and consistently turned a considerable profit. However, now the cooperative must wait to see how long radioactive contamination will impede its hardwood production business.

Commercially grown konara oak and other broadleaf trees regenerate by harvesting trees under 20 years old, as new sprouts stem from the stumps. This coppicing method produces up to three main stems from each stump (Fig. 12.4); the stem's straight portions are used for mushroom cultivation, while the curved or gnarled portions are pulverized for sawdust production. The market price of mushroom logs is currently high, and is two- to fourfold the price of softwood products, such as cedar timber and wood chips for paper production (Hayajiri 2013). Consequently, mushroom log production is a valuable aspect of forestry, although after the Fukushima nuclear accident, this is not the case for the Fukushima Chuo Forest Cooperative.

Before the Fukushima nuclear accident, the Fukushima Chuo Forest Cooperative produced mushroom logs within $20 \mathrm{~km}$ of the nuclear plant. After the accident, 


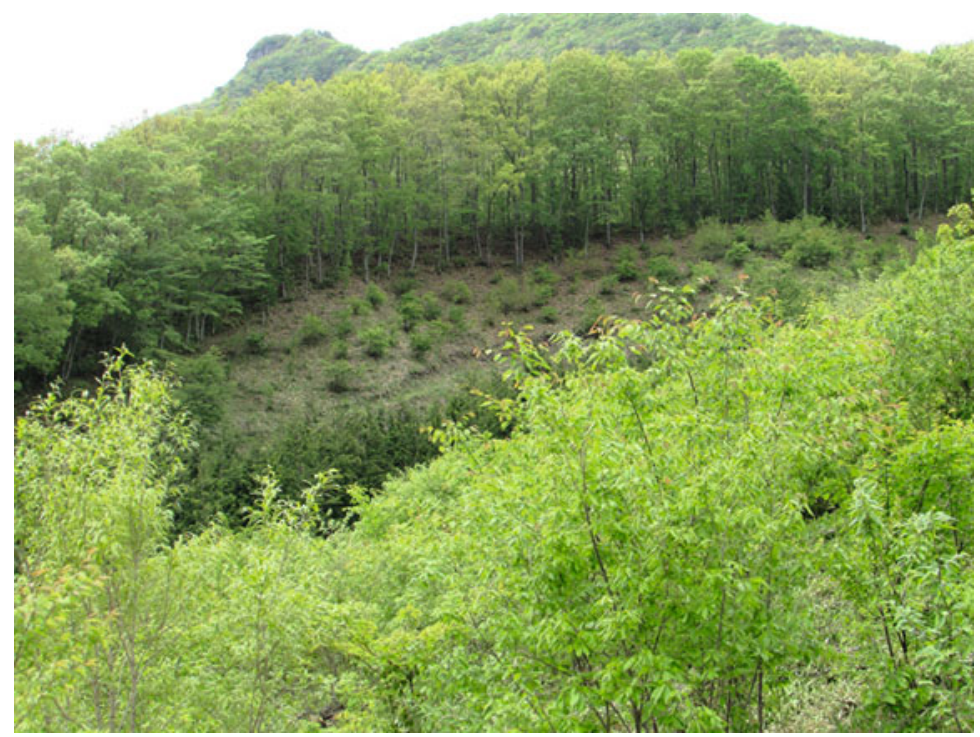

Fig. 12.3 A coppiced forest at Miyakoji, Tamura, Fukushima. Two-year-old coppices are in the foreground; an oak forest that has grown beyond its optimal harvesting date due to the Fukushima nuclear accident is in the background

these areas were under evacuation orders until April 2014, at which point forestry activities could resume. Currently, the cooperative's primary concern is whether radioactive contamination levels of konara oak planted now will be below the allowable limit when harvested in 20 years. Trees contaminated after the accident undoubtedly lost their value, but predicted effects on mushroom logs harvested in 20 years will affect forest management. If prospects for future harvests are not favorable, then a major reappraisal of forestry management and production is required. However, if it is possible to produce mushroom logs below allowable radiation contamination levels, then current forest management practices will suffice. Unfortunately, we cannot predict radiation levels of konara oak grown under current conditions.

\subsubsection{Resuming Mushroom Log Production}

Timber becomes radioactive when radioactive particles migrate into its tissues from the bark or through the roots, and predicting the amount of radioactive cesium that will accumulate in konara oak trunks over the next 20 years is necessary for the mushroom industry. The half-life of ${ }^{134} \mathrm{Cs}$ is 2 years, so in 20 years, it will decrease to $1 / 1000$ of the present level, meaning that only ${ }^{137} \mathrm{Cs}$ is of concern. However, currently, even this isotope alone is above total allowable radiation limits for mushroom cultivation media. 

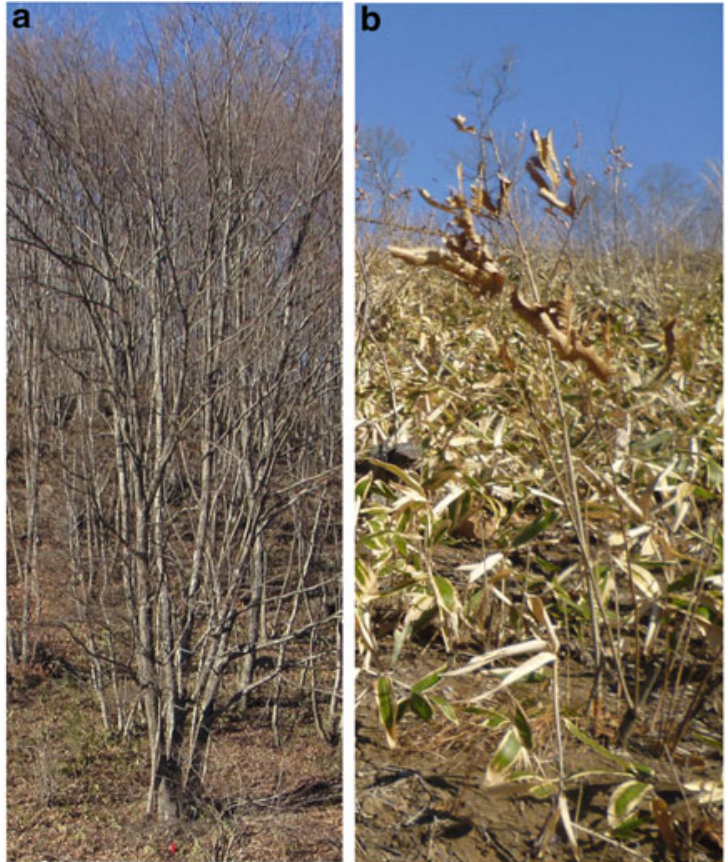

c

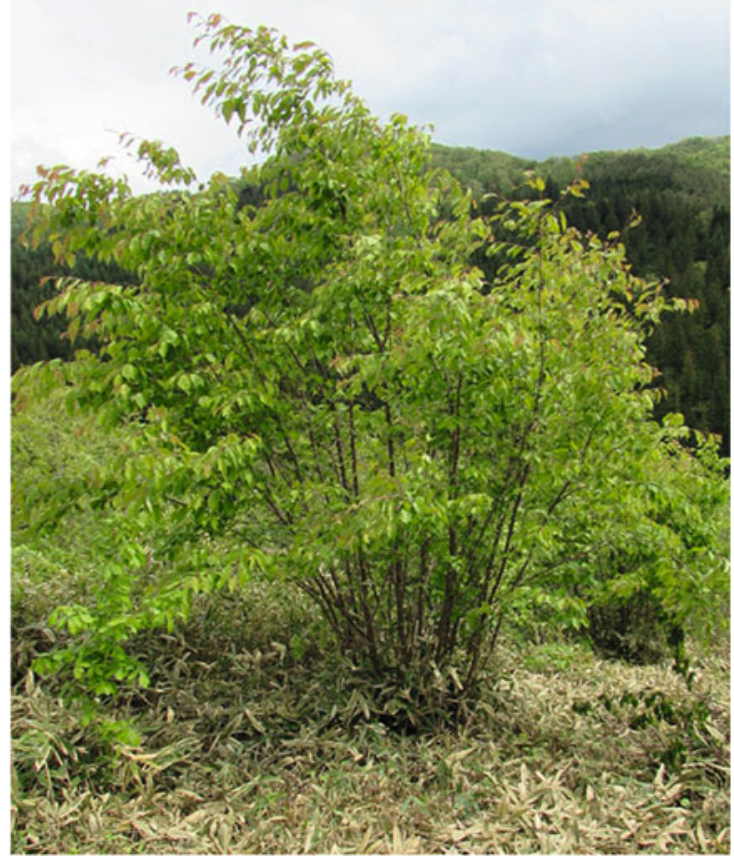

Fig. 12.4 Coppicing regeneration of Quercus species (a) Mature tree; (b) New planting; (c) Coppicing 
In regenerating coppices, ${ }^{137} \mathrm{Cs}$ enters from the belowground stump and roots, while in newly planted trees, the only source is through root uptake. Therefore, contamination of newly planted trees depends on soil contamination and the tree's ability to absorb contaminants (transfer factors). Studies near the Chernobyl accident have found that transfer factors vary from 10 to 100 -fold and depend on soil contamination levels and characteristics, and tree species and age (Shcheglov et al. 2001). However, data regarding how tree species and soil type can influence ${ }^{137} \mathrm{Cs}$ uptake in Japanese hardwood trees are insufficient.

Moreover, radiation dynamics in trees regenerating from stumps are more complex than in newly planted trees. For instance, underground portions of the stump have also been subject to considerable contamination, which would affect contamination of the coppices. However, there is limited information concerning root contamination. In addition, although coppices grow more rapidly than newly planted trees because of the considerable carbohydrate stores in the stump, ${ }^{137} \mathrm{Cs}$ migration rates into the coppice are unknown. Migration rates differ greatly depending on the growth characteristics of the tree. If Cs migrates to the roots and inhibits uptake of new cesium, then tree growth over 20 years would dilute the $\mathrm{Cs}$ in above- and below-ground tissues. When considered with radioactive decay, contamination in new coppices may be considerably lower than in trees directly contaminated from the Fukushima accident. However, present knowledge regarding radioactive contamination in hardwood trees is insufficient to confirm this speculation.

To predict ${ }^{137} \mathrm{Cs}$ contamination behavior in coppices, further research into trees' absorption of $\mathrm{Cs}$, its migration through the bark into the tree, and its movement and distribution in the tree is required. Twelve years after the Chernobyl accident, ratios of radioactive ${ }^{137} \mathrm{Cs}$ and stable ${ }^{133} \mathrm{Cs}$ were constant throughout pine and birch stands (Yoshida et al. 2004). This shows that the Cs concentrations in forest ecosystems reached an equilibrium between stable isotopes and other elements. Conversely, since the Fukushima accident, ${ }^{137} \mathrm{Cs}$ concentrations in konara oak and cedar trees have not reached an equilibrium, and continue to increase (Mahara et al. 2014). This may provide insight into ${ }^{137} \mathrm{Cs}$ dynamics in konara oak trees, but does not present the overall picture.

\subsection{Conclusions}

Harvesting logs for mushroom cultivation has been an important part of the forestry industry in Fukushima. However, if it is impossible to produce logs with a radioactive Cs level below $50 \mathrm{~Bq} / \mathrm{kg}$ by using standard production methods, the industry is in a perilous position and must consider significant restructuring. After 100 years, radioactivity will naturally decay to $10 \%$ of current levels; however, the forestry industry cannot wait that long and must continue operations in radioactively contaminated forests despite the associated challenges. 
Mushroom log production requires a 20-year cycle, but softwood cedar and cypress used for timber requires at least a 40-year cycle. In Japan, there has been commercial mushroom cultivation by the forestry industry for about 60 years; during previous centuries, hardwood coppices were mostly sources of firewood and charcoal. Remnants of charcoal kilns remain in various forests throughout Japan. Previous forestry practices were long lasting, but during the energy revolution in the 1960s, change happened quickly, and mushroom cultivation is now a major aspect of the forestry industry. In forests with radiation contamination, we must consider implementing historical forestry practices, as forests enrich people's lives in many ways and we should investigate all available options. However, we must also look to the future to make decisions regarding our livelihoods. Fukushima Chuo Forest Cooperative's future management policies are continually developing and depend on further research to understand the problems associated with radioactive contamination of forests.

Open Access This chapter is distributed under the terms of the Creative Commons Attribution Noncommercial License, which permits any noncommercial use, distribution, and reproduction in any medium, provided the original author(s) and source are credited.

\section{References}

Arkhipov NP, Kuchma ND, Askbrant S et al (1994) Acute and long-term effects of irradiation on pine (Pinus silvestris) stands post-Chernobyl. Sci Total Environ 157:383-386. doi:10.1016/ 0048-9697(94)90601-7

Forestry and Forest Products Research Institute (2012) Results of monitoring radioactive material in stream waters in rainy season. Accessed 15 Nov 2014 (in Japanese)

Forestry Agency (2011) Nation-wide liaison conference of supply and demand of mushroom logs. http://www.rinya.maff.go.jp/j/tokuyou/shiitake/jyukyuukaigi.html. Accessed 20 Nov 2014 (in Japanese)

Forestry Agency (2012a) Trial calculations of exposed dose for a man living in a room surrounded by wood. http://www.rinya.maff.go.jp/j/press/mokusan/pdf/120809_1-02.pdf. Accessed 10 June 2014 (in Japanese)

Forestry Agency (2012b) Revision of index for mushroom logs and culture medium for mushroom beds. http://www.rinya.maff.go.jp/j/press/tokuyou/120328_2.html. Accessed 15 Nov 2014 (in Japanese)

Forestry Agency (2013) Development of a guideline for cultivation management of log-cultured mushrooms to reduce radioactive materials. http://www.rinya.maff.go.jp/j/press/tokuyou/ 131016.html. Accessed 20 Nov 2014 (in Japanese)

Forestry Agency (2014a) Project of technological development and verification for prevention of radioactive material diffusion from forests. http://www.rinya.maff.go.jp/j/press/kaihatu/ 140822_1.html. Accessed 20 Nov 2014 (in Japanese)

Forestry Agency (2014b) Survey findings of distribution of radiological materials within forests in fiscal year 2013. http://www.rinya.maff.go.jp/j/press/ken_sidou/pdf/140401-01.pdf. Accessed 10 May 2014 (in Japanese)

Forestry Agency (2014c) Change of major domestic forest products and mushrooms. http://www. e-stat.go.jp/. Accessed 15 Dec 2014 (in Japanese) 
Forestry Agency (2014d) Stats of forestry: forest products, lumber industry. http://www.rinya. maff.go.jp/j/kouhou/toukei/. Accessed 15 Dec 2014 (in Japanese)

Forestry Agency (2014e) About withholding conditions of mushrooms and mountain vegetables. http://www.rinya.maff.go.jp/j/tokuyou/kinoko/syukkaseigen.html. Accessed 15 Dec 2014 (in Japanese)

Forestry Agency (2014f) Annual report on forest and forestry in Japan, fiscal year 2013. Forestry Agency, Ministry of Agriculture, Forestry and Fisheries, Japan

Fukushima Lumber Cooperative Unions (2012) Voluntary standard for radioactive safety. http:// www.fmokuren.jp/publics/index/24/. Accessed 25 Sept 2014 (in Japanese)

Hasegawa M, Ito MT, Kaneko S et al (2013) Radiocesium concentrations in epigenic earthworms at various distances from the Fukushima nuclear power plant 6 months after the 2011 accident. J Environ Radioact 126:8-13. doi:10.1016/j.jenvrad.2013.06.006

Hashimoto S, Matsuura T, Nanko K et al (2013) Predicted spatio-temporal dynamics of radiocesium deposited onto forests following the Fukushima nuclear accident. Sci Rep 3:2564. doi:10.1038/srep02564

Hayajiri M (2013) Efforts of a forestry cooperative after radiation disaster: its actual circumstances and challenges. J Coop Study Niji 643:71-79 (in Japanese)

Hayashi S (2013) How radiocesium deposits and moves within a forested area. Natl Inst Environ Stud News 32:7-9 (in Japanese)

Hiyama A, Nohara C, Kinjo S et al (2012) The biological impacts of the Fukushima nuclear accident on the pale grass blue butterfly. Sci Rep 2:570. doi:10.1038/srep00570

International Atomic Energy Agency (2002) Modeling the migration and accumulation of radionuclides in forest ecosystems. IAEA, Vienna, pp 1-127

International Atomic Energy Agency (2006) Environmental consequences of the Chernobyl accident and their remediation: twenty years of experience, Report of the Chernobyl forum expert group "Environment". IAEA, Vienna, p 166

Ishida K (2013) Contamination of wild animals: effects on wildlife in high radioactivity areas of the agricultural and forest landscape. In: Nakanishi TM, Tanoi K (eds) Agricultural implications of the Fukushima nuclear accident. Springer, Tokyo, pp 119-129

Kalač P (2001) A review of edible mushroom radioactivity. Food Chem 75:29-35. doi:10.1016/ s0308-8146(01)00171-6

Mahara Y, Ohta T, Ogawa H, Kumata A (2014) Atmospheric direct uptake and long-term fate of radiocesium in trees after the Fukushima nuclear accident. Sci Rep 4:7121. doi:10.1038/ srep07121

Ministry of Health, Labor and Welfare (2011) Handling of food contaminated by radioactivity. http://www.mhlw.go.jp/english/topics/foodsafety/dl/food-110317.pdf. Accessed 20 Nov 2014

Ministry of Health, Labor and Welfare (2012) Measures against radioactive contamination of food caused by the accident. http://www.mhlw.go.jp/shinsai_jouhou/shokuhin.html. Accessed 20 Nov 2014

Ministry of Health, Labor and Welfare (2013a) Revision of guideline on prevention of radiation hazards for workers engaged in decontamination works. http:/www.mhlw.go.jp/english/ topics/2011eq/workers/dr/dr/ri_1226_21.html. Accessed 20 Nov 2014

Ministry of Health, Labor and Welfare (2013b) Survey of dietary intake of radionuclides (September to October 2012). http://www.mhlw.go.jp/english/topics/2011eq/dl/index_food_ policies_20131011_2.pdf. Accessed 20 Nov 2014

Murakami M, Ohte N, Suzuki T et al (2014) Biological proliferation of cesium-137 through the detrital food chain in a forest ecosystem in Japan. Sci Rep 4:3599. doi:10.1038/srep03599

Neda H (2013) Reducing radiocesium uptake by cultured mushrooms. Tokusan Jouhou 35:8-12 (in Japanese)

Nihei N, Tanoi K, Nakanishi TM (2015) Inspections of radiocesium concentration levels in rice from Fukushima prefecture after the Fukushima Dai-ichi nuclear power plant accident. Sci Rep 5:8653. doi: $10.1038 /$ srep08653 
Nuclear Regulation Authority (2014) Environmental radioactivity and radiation in Japan. http:// search.kankyohoshano.go.jp/servlet/search.top. Accessed 15 Dec 2014 (in Japanese)

Nuclear Regulation Authority (2013) Fundamental perspectives for countermeasures for safety and relief towards the returns of residents (draft). https://www.nsr.go.jp/committee/kisei/ h25fy/data/0032_01_1.pdf. Accessed 20 Nov 2014 (in Japanese)

Shcheglov AI, Tsvetnova OB, Klyashtorin AL (2001) Biogeochemical migration of technogenic radionuclides in forest ecosystems. Nauka, Moscow, p 235

Takahashi M (2013) Contamination of radioactive cesium in the forest ecosystem in Fukushima and the necessity of long-term monitoring. Trends Sci 18:68-71 (in Japanese)

Valentin J (2007) The 2007 recommendations of the international commission on radiological protection. Ann ICRP 37:1-332

Yamada T (2013) Mushrooms: radioactive contamination of widespread mushrooms in Japan. In: Nakanishi TM, Tanoi K (eds) Agricultural implications of the Fukushima nuclear accident. Springer, Tokyo, pp 163-176

Yoshida S, Muramatsu Y, Dvornik AM et al (2004) Equilibrium of radiocesium with stable cesium within the biological cycle of contaminated forest ecosystems. J Environ Radioact 75:301-313. doi:10.1016/j.jenvrad.2003.12.008 